\title{
MULTIPLE IDENTITIES, CITIZENSHIP RIGHTS AND DEMOCRATIZATION IN AFRICA
}

\section{'LAI OLURODE \\ University of Lagos, Lagos, Nigeria.}

This particularistic and exclusionary form of identity politics has intensified in recent years within and among nations..... It is responsible for some of the most egregious violations of international humanitarian law and, in several instances, of elementary standards of humanity.... Negative forms of identity politics are a potent and potentially explosive force. Great care must be taken to recognise, confront and restrain them lest they destroy the potential for peace and progress that the new era holds in store (Kofi Annan, The Guardian, (Nigeria) 1997:8).

Single or multiple identities underlying fears of losing national culture is an implicit belief that identities are singular. But people do not have single fixed identities. They have multiple and often changing identities and loyalties. Accepting Multiple Identities is a major social transformation. But history shows that it does happen. Almost all European countries 
have undergone such a transformation. (pp.101-102 Human Development Report 2004).

\section{INTRODUCTION}

The colonial project which was foisted on Africa largely by Britain and France left the continent more dis-united and generated more consciousness among groups about their distinctiveness and those factors that separated them ("we") from others ("they"). One of the most enduring outcomes of the colonial contact was the creation of self-doubt and the negation of identity formation among the dominated population. Frantz Fanon (1969:200) gave an eloquent account of this development when he said inter alia that

Because it is a systematic negation of the other person and a furious determination to deny the other person all attributes of humanity, colonialism forces the people it dominates to ask themselves the question constantly: In reality, who am I?

Under the guise of anthropology as a scientific enterprise, scholars made fortunes out of highlighting the features of warrior tribes or what were referred to as the martial races, and their kingdoms, state and acephalous societies. The presence of large ethnic groups, some of them far larger than those in Europe, was conveniently ignored so that the label and stigma of tribe would stick. In the main, some of Africa's complex socio-economic and political organizations were ignored by European authors.

In the struggle that culminated in Africa's independence, the different groups were, in most cases, forced to coordinate their struggle in order to be free of colonial domination. It must be remembered that the road to independence was bloody in most cases, though in some, it was granted on a platter of gold. The Maumau uprising in Kenya and the coal-miners strike as well as the Aba Women's riots in Nigeria symbolized bloody resistance to colonialism and its methods. Kenya's rural producers objected to land redistribution away from peasant farmers. The Maumau resistance was severest in settler regions where there were plantations. It was in essence, Kenya's peasants resistance to 
the colonial occupation of their land. Really, there were many features of the colonial society that were provocative: segregation in housing, employment and schooling, and the killing of natives for pleasure.

The colonial setting thus produced a culture of violence and brutality directed at the natives. The claim of a civilizing mission in Africa by the colonial powers was indeed absurd. Africa later realised its naivety in endorsing, generally without much resistance, the European incursion into its territory, the enslavement of its people and the exploitation of its resources. This awareness, however, came rather too late. The damage had been done. Communities had been decimated, resources looted and ways of life had been adulterated. The trust basis of society and the perception of others as the extension of the self almost became extinct. A world-renowned novelist, Chinua Achebe, had provided an excellent summary of this development in Things Fall Apart, and for Africa the centre indeed no longer holds. In the definition of the colonisers, to be accepted as modern, Africans must evidently demonstrate a measure of distance from their culture and thus from their roots. Africans were and still are expected to exhibit a hatred for themselves if they are to be described as modern thus, part of globalisation - a new euphemism for slavery and dependency. Really, how can one hate the self which is what an individual's denial of his culture comes to? Unfortunately, in several facets of life in Africa, self-denial of our essence lingers.

The colonial constitutional development created a new consciousness by making ethnic affiliation a major element in political socialization and leadership recruitment, but at independence, the goals that were set included national integration rather than regional or ethnic solidarity. What a paradox? These goals were incompatible as loyalty to the ethnic or regional groups was difficult to transfer to the nascent state. In fact, as for the majority, the notion or the existence of the state was only on paper or an idea of the empire builders, itself an afterthought as it was after World War II that preparations were commenced, shoddy ones at that, for the transfer of power to the colonial subjects. The colonial order was strident in its opposition to collaborative activities between ethnic groups. Colonialism triumphed mostly 
on the divide and rule tactics.

Thus individuals in the post-colonial African society display multiple identities. These identities are variously expressed. An individual's membership of the new nation-state is a nascent form of identity expression. The individual's membership of his ethno-religious group is much older and more enduring than his membership of the new nation-state. The individual may also be a member of the recently-formed employee's association - the Trade Union Congress. The identities that can be paraded are indeed numerous. These multiple identities come to play in moments of critical decision-making and these identities do affect an individual's life chances, the socio-economic and political opportunities that are manipulable by him. These loyalties, rather than waning, have waxed over the years and they do have implications for the enjoyment of citizenship rights and Africa's democratization processes.

These identities are often conflicting in the interests that they seek to project and protect. They may, in fact, obstruct the universalistic and libertarian principles on which democracy is premised. They are, however, not fixed as they are open to activation or suppression or even transformation depending on the events in the social environment (see the opening sentences by Kofi Annan). There are certain objective realities that dictate which of the several identities comes to the fore. State actors in Africa seems to prefer the fragmentation of identities as these make the formation of a formidable opposition that could challenge the state's hegemonic rule a remote possibility. The state could thus act surreptitiously to encourage the factionalisation and disintegration of strong civil societies in order to ward off strong counter-hegemonic forces and thus weaken those identities that are considered as undesirable. A faction of the state, armed with strong identity credentials, could also seek to pull down the state. The foregoing issues are made more explicit in the following discussion.

Some definitions of the key words in this paper are appropriate. The Harper Collins Dictionary of Sociology refers to identity as the sense of the self that develops as the child differentiates from parents and family and takes a place in society. The sense of identity could be based on ethno-religious and temporal factors or geography. 
It is often the basis of social action and political behaviour. The sense of identity deepens in a plural society where a group, just for reasons of its being different, suffers discrimination. Identity could also be based on some physical characteristics. Citizen's rights refer to those rights that one enjoys by virtue of one's membership in a country. The scope of these rights owes a lot to the profile of the state and political struggle. By democratization, it has meant the opening up of the political space, the demise of military rule and the introduction of multi-party democracy in place of the oneparty state. However, we could have multi-partism with individuals not really having alternatives to choose from.

This paper's objective is to highlight how multiple identities may facilitate or hinder access to citizenship rights. Multiple identities are paraded for a variety of reasons. They may have their own relative autonomy but somehow they connect individuals to specific rights and privileges from which others may be excluded. Democracy, on the other hand, claims universalistic ethos. Theoretically, therefore, democracy and the disclosure of multiple identities cannot co-exist as they have potentially conflicting appeals.

In the second section, the paper raises some theoretical issues while in the third section, the paper focuses on identity politics and democratization in Africa and highlights how the outcome has impacted on citizenship rights. The conclusions are contained in section four where I issue a caution on the problem of politics of social exclusion as I attempt to plot the path to a sustainable democratic future for Africa in the midst of multiple identities. By its very nature, democracy does not admit nor approve of group rights yet in Africa, groups claim to property (until recently) eminently override the claims of individuals. The challenge, therefore, for scholars in and about Africa, is how to make the practice of democracy in Africa become more accommodative and tolerant of plurality of identities and thoughts while simultaneously advancing citizenship rights and thus democratic consolidation.

\section{SOME THEORETICAL ISSUES}

To those who believe that globalization is a most desirable and beneficial phenomenon, the resistance to it remains a major puzzle. In many parts of Africa, Asia, the middle East and Latin America, 
what globalization holds out are believed by many to be false. The more the intensity and profundity of the change process, the more enduring seems the value system that contradict the move toward a uni-polar global hegemony. This resistance has several dimensions. The most worrying is that which seeks to emphasize and even adore the distinctiveness of a group, its homogeneity and those characteristics which separate it from those of the others. In the extreme, this position does not admit of ethno-religious and political pluralism. This world view was similar to the position of those who regard the triumph of western civilization as incontrovertible and inexorable. An average African, perhaps an Asian too, simultaneously discloses multiple identities - a village person, a town's man or woman, a Muslim or Christian, an active member of an ethnic association, an employee and employer, a politician, member of an old school association, an age grade member, a unionist, an active member of a neigbourhood association and perhaps a lineage head. The demand of these diverse associations on an individual may conflict and if simultaneous, is capable of creating a dilemma for the individual actor.

Social formation in Africa is complex, and identities may appear to be ambiguous and conflictive as individuals simultaneously occupy many roles. In my field work experiences, I have come across individuals who are labourers, farmers, employers and shop owners at the same time. Most Africans actively participate in the formal and the informal spheres simultaneously. The playing out of many roles sequentially or simultaneously is seen as normal by many. A Nigerian politician describes himself in the following terms is indeed typical of others:

I am a living laboratory of my age.... I am at once the cocoa farmer, mercantile clerk, the civil servant, the petty trader, the transporter, the capitalist and the intellectual (and now the politician) all materials for the study of the social scientist (Adegoke Adelabu quoted in Post and Jenkins, 1973:33).

Where individuals parade multiple identities, role multiplicity sets in which in turn complicate social class formation and political action as well. Thus an

analysis of politics, religion, kinship were ....... a 
part of any adequate account of social change as economics and that the manner of their interaction, in any particular society, must be a matter for open enquiry, rather than the known consequences of a universal model of society (Peel, 1983:6).

How to account for the re-surgence of identity based politics and its enduring nature in the midst of globalization remains a major challenge for academic and state actors especially those who believe in a unipolar world and read too far into the end of the cold war as signifying 'The End of History' (Fukayama, 2001). Some authors indeed had predicted the ultimate triumph of western civilization and its values in its competition with other civilizations (Hunttington, 2001). The event of 9/11 was however a sad reminder that there are people in the world that do not see the reality that others cherish, who reject the consumption-oriented society and who do not subscribe to the values which others hold dear. The end of history is thus further away. The demise of bipolarism and of the Russian empire may not really signal the end of history nor the ultimate triumph of western values. The future is really pregnant with a lot of meanings. It is worthwhile to recognize that identities are not static, they get transformed and are open to manipulation. In their transformation, groups that were otherwise once antagonistic may be forced to pool resources and sink their differences in order to confront what is perceived as a common monster. The forging of political alliances are often dictated by vested interests and these are often open-ended, and practical realities would dictate which alliances are most feasible and which of the identities should be on the front burner.

In both the developing and even developed countries, groups within states whether these groups are religious or ethnic groups, are claiming rights that are exclusive to them and from which others are to be excluded. Indeed, identity-based politics has not abated whether in Spain between the Basques and the Spaniards; or in Belgium between the Fleming and the Walloon; or in the Irish Republic between the Catholic and the Protestants; or in America between the American-whites and the other hyphenatedAmericans; or in Nigeria between the different ethnic groups; or 
in Rwanda between the Hutu and Tutsi. In its early history, the American-whites did not all have the same rights - the timing of migration to America was initially important in the determination of political rights (see Archdeacon, 1984).

There has emerged a serious contestation between the rights being claimed by those who consider themselves and their groups as indigenes and those who are considered by them as "strangers" and who may also see themselves as such. Behaviour and attitudes that have practical outcome for social exclusion are often premised on these distinctions between the notions of "citizens" (indigenes) and "strangers." Mamdani (1996) had referred to this dichotomy between citizens and strangers in terms of citizens and subjects, whereby the colonial regime administered the people of the colonies under two laws - one for the citizens and the other for the subjects. The exclusionary practices that flow from this dichotomy do occasionally produce overt behaviour that could burst out. The social fabric of society could be eroded thus endangering political stability and peaceful co-existence of groups. The modern state is thus under pervasive pressure from groups that make competing claims over the state's scarce values. The state is hardly in a position to meet the claims of competing groups over state resources. Whatever our conception of the modern state, in spite of all its paraphernalia and sophisticated architecture, is after all, preoccupied with the regulation of the relationship between diverse groups and interests in society.

In the relationship in which individuals and groups become entangled, they are often not equally treated. The denial of access to significant resources may endanger political stability and the enjoyment of citizenship rights by identifiable groups in society. Social and political inequality promote feelings of alienation and frustration. Political participation becomes encumbered. The connotation of citizenship as 'full members of the community' (Marshall and Bottomore 1992: 18) is denied to those who are perceived as being different from others. There are three kinds of rights that have become popular - civil (rights of free speech, right to worship etc); political (right to vote and be voted for); and social (right to housing, health, etc). These rights, even under advanced capitalism can readily be abridged or compromised. 
The concepts of social prejudice and stereotype are important in understanding the ways in which people judge and treat others (the out-group) who are different from them (the in-group). Somehow, through the process of socialization, individuals begin to construct their identities. As individuals become full-fledged members of their society, they unconsciously acquire its cognitive map of 'we' and 'they' and they thus inevitably inherit a world that had been perfected by others. Individuals' view of reality become tainted from birth. This view often fails to recognise other systems of seeing and being. The end-product of this process could be hatred or love for others that are adjudged as being different. This point raises some methodological issues which are outside the scope of this discussion.

Bibby's (1959) work dealt extensively with how prejudice impact on our behaviour toward others. Prejudice forces people to draw conclusions before having the opportunity to interact with others. Though prejudice is learned, it is difficult to unlearn even when compelling information to the contrary is presented. Hatred is an extreme manifestation of social prejudice. In this connection, I can mention the massacre of the Jews during the second world war. There was also the hatred of the Arabs and Islam in America and Europe after the event of September 11 (see Mamdani, 2004). In France, the ban on head ties was believed to be directed at Arab women. In Rwanda, the mutual distrust and hatred between the Tutsi and Hutu, and between the Croatia and Serbs in Yugoslavia are examples of this point. The human tragedy in the Darfur region in Sudan is the outcome of social prejudice, social exclusion and intolerance. The Darfur region in southern Sudan had been the cynosure of world attention because of the Sudanese genocidal attacks on the non-Arabs. This tragedy is a direct result of the Sudanese government's failure to manage multiple-identities and pluralism.

As a response to the centrifugal tendency and the exclusionary politics that social prejudice and stereotype may generate, states have often designed different political contraptions to contain the divisive implications. It would be recalled however, that colonial rule had previously amplified the wedge that might have existed previously between groups. Thus, as a prelude to its politics of 
divide and rule through the indirect rule system, the ethnographers and anthropologists of Africa had altered the Africans' mode of thought. This was accomplished through the categorization of Africa into different ethnic and linguistic groups with little regard to common identities. Yes, differences existed, but these are often exaggerated to make nonsense of any possibility of reconciliation or coordinated action against colonial domination. The concept of tribe was used to refer to the people of Africa irrespective of the level of social and population development. But European groups with even lower population and less sophisticated political architecture were described as nations. That the anthropologists and the missionaries were the handmaidens of colonialism could not be disputed and in many instances they collaborated and their activities reinforced each other. It did not, therefore, take much time before Africans began to think of themselves in terms not of their own making (Grinker and Steiner, (1997:47).

The intellectual support which was provided for colonialism, the self-doubt, and social prejudice that thereby became fostered cannot be regarded as insignificant. Among Europeans and Africans alike, the thinking that some people were unprogressive and unintelligent whereas other groups were portrayed as the opposites became widespread. The work of Levine (1966) on Dreams and Deeds was one of such classic works in the fostering of social prejudice. Levine's work identified the Ibos as more mobile on the indices of modernization and were followed closely by the Yoruba with the Hausa-Fulani trailing far behind the two major groups. The practical consequence of this 'scientific' endeavour and similar other works was a portrayal of the different African groups as not only incompatible but with antagonistic and irreconcilable aspirations. A year after this publication, the civil war broke out in Nigeria. It is not being suggested that the book was the cause of the Nigerian civil war but such anthropological works fueled feelings of group hostilities. Such writings had offered enough justifications for the exclusion of certain groups from socioeconomic opportunities.

However, the fallacy of this social science thought was evident in Nigeria where the Hausa-Fulani ethnic group was thought of by Europeans as unprogressive, unintelligent and backward. These 
writings were in the main ideological and teleological hence Claude Ake's reference to social science in Africa as imperialism (Ake, 1979). African leaders, however, continue to fan the embers of hatred and parochialism as these suit them. In Nigeria for example, the Hausa-Fulani, mainly because the British handed over power to the group believing that they were more pliable and conservative have come to see themselves as destined to rule. This remains strong and the northern governors once said '... whatever anyone may say, the incontestable fact remains that in the political equation of this country, the North holds the ace. In fact, if there is no North, there will be no Nigeria' (Sunday Punch, November 19, 2000). This hardened prejudice makes nonsense of the dialogue under the auspices of the National Political Reform Committee which was inaugurated on February 21, 2005. Not surprisingly, the issues of resource control, resource sharing and of which ethnic group should rule dominated discussions at the meetings of the Political Reform Committee. The participants did not demonstrate equal concern to wealth creation, good governance, social justice and how to overcome mutual suspicion between groups.

Unless social prejudice is moderated, the practical outcome would be that some individuals would come to be defined as strangers (or settlers) and would be regarded as having no full citizenship rights which are available to the indigenes. The citizenship claims which are open to the non-indigenes became qualified and the foundation for treating them unequally and with disdain had become established though sometimes contestable. In these ways, identity politics become antithetical to the notion of democracy and the rule of law as outlined by Montesque and John Locke. What really is left of citizenship rights in the absence of equality before the law and equality of access to the market, education, healthcare and housing among others? Without the right to vote and the right to property, citizenship rights are deprived of all their vitality and spirit. Some of the ways in which identity politics constitute a direct challenge to the nuances of democracy and the very notion of citizenship are discussed in the next section. 


\section{IDENTITY POLITICS AND DEMOCRATIZATION}

Identity politics revolves around the parade of particularistic features as the basis for political participation and inclusion as well as the enjoyment of citizenship rights and privileges. This identification could be such parameters as gender, ethnic, language, religious or regional affiliation. In India for example, distinctions are made between the different caste groups - some are regarded as free born and they exercise more political, social and civil rights than the others. Marriage and other forms of interaction are not often permitted between the groups in order to avoid contamination. In the eastern part of Nigeria, the Osu caste is discriminated against in marriage, economic and political sphere. Even in the United Kingdom, it is difficult for someone who is not from the mainland to become the Prime Minister. Scotland not only has its own judiciary but it is also set to have its own foreign mission in such countries as China. The battle for self-determination by the Basque is believed to have reached its crescendo. The Fleming and the Walloon in Belgium continue to contest their ethnic autonomy. Also very early in its development, there were qualifications as to who can become senators or representatives in the American Congress. Foreign-born Americans were not then on the same footing as home-born Americans in terms of citizenship rights.

Identity politics is not a phenomenon that is unknown to Western European or North American politics nor is it disappearing under advanced capitalism. To be a representative or a senator, one must have been a citizen for at least 7 or 9 years, respectively, prior to assuming office. This provision was contained in Article I. In Article II of the U.S. Constitution, it was decreed that no immigrant naturalized after the adoption of the Constitution could become President or Vice-President (see Archdeacon, 1984:54).

Because it emphasizes political participation and the exercise of rights that draw from particularistic principles, the universalistic and libertarian notion of democracy become easily compromised. Even where the codes of entitlements to participation are written down, there are norms and practices which define those that are to be included. Under such a system, competitive politics is handicapped. Political roles become rigidly defined and those who capture political power see it as divinely ordained. In a multi-ethnic society, however, individuals who transcend identity politics may 
have an upper hand and wider base to recruit supporters from. There are individuals whose identities are not straightforward either for reasons of marriage or birth. Though Soni Ghandi led the Congress Party to victory, she could not become the Indian Prime Minister because she was regarded as a foreigner - an Italian by birth but an Indian by marriage. During her campaign, she herself had made use of the Ghandi's family respected identity.

This particularistic notion of politics is more common in Africa and in spite of Africa's claim to be experimenting with democratization, instances of erosion of democratic and citizenship rights are on the ascendancy. I shall refer to four case studies to illustrate the vibrancy and not the demise of identity politics in Africa as has been theoretically and enthusiastically announced by some authors. I relied on the internet and newspapers for most of this section. Sometime in 1996, the then President of Zambia, Frederick Chiluba, (using the machinery of his Movement for Multiparty Democracy), altered the constitution of the country to prevent Kenneth Kaunda from standing for elections. When Kaunda challenged the constitutional provision which sought to strip him of his Zambian citizenship, the court ruled that Kaunda, being born of Malawian parents and having not renounced his Malawian nationality, had thus governed Zambia illegally from 1964-1991. Of course, it was clear that the intent was to prevent Kaunda from exercising his political rights in the 1996 election.

In Cote d'Ivoire, identity politics came to the fore after the death of its former dictator - Felix Houphount-Boigny-in 1993. Henry Konan Bedie had assumed the presidency of the once buoyant West African cocoa-producing economy. Bedie sooner than later introduced a new concept of 'Ivorite' - real Ivorians as different from foreigners. The hidden agenda being to regulate political competition. Alassane Quattara was the first casualty and the only target. Though many became victims of this obnoxious policy as they were disenfranchised (because of their new identity as foreigners), Quattara who was the main target was prevented from contesting the presidential election. This politics of exclusion remains at the centre of the crisis in the once peaceful and buoyant Cote d'Ivoire that had previously been paraded by France as a model of a progressive economy and stable country. The groups 
at war in Cote d'Ivoire are yet to lay down their arms.

Sometime in 1982, Nigerians woke up to learn of the deportation of Abdul Rahman Shugaba, the then majority leader of the House of Assembly in Borno State, Nigeria. The allegation against him by the then civilian administration was that he was not a Nigerian but from a neighbouring republic. Shugabi's real offence, however, was that he was being too critical of the then federal government. The federal government was also uncomfortable with Shugaba's association with the then progressive politicians in southern Nigeria. The ruling northern political party (the National Party of Nigeria) thought that Shugaba, being a northerner, should identify with his fellow northerners and their dominant political party. Though the court ruled that his deportation was illegal, he suffered serious infraction of his fundamental rights as a citizen.

The events in Togo, West Africa brought to the surface the resilience of identity politics. After the death in February, 2005, of President Eyadema, who had ruled Togo since 1967, his son, Faure, was hurriedly sworn in after the constitution had been amended to prevent the Speaker from ascending to power. The only qualification of Faure was his being the son of Eyadema. Of course, this provoked a series of demonstrations and it attracted sanctions from ECOWAS and the African Union. Elections were later held and Faure was elected.

The above illustrations have shown how identity politics can obstruct the wheel of democratization as it erodes the political rights of citizens. It could sometimes degenerate into forced migration and mass displacement of people who are routinely turned into refugees as the struggle for citizenship rights assume fratricidal dimension. There are ample instances of this in Africa. Once the political rights of citizens are violated, the assault on other rights become common. Identity politics can, in this way, constitute impediments to development. In Nigeria for example, there are parts of the country where land rights may not be granted to non-indigenes and where those who regarded as such are confined to specific areas meant for strangers. So frustrating to Nigeria's President was this phenomenon of "strangers" and "settlers" that he declared in 2004 that 'All Nigerians are settlers" (The Punch, July 3, 2004). The manipulation of multiple identities 
endangers the very tenet of liberal democracy. In Nigeria, it poses a direct challenge to property rights (see Nnoli, 1978:115-116). In the conclusions which now follow, I outline the ways in which multiple identities may obstruct citizenship rights and thus the consolidation of effective democratization in Africa.

\section{CONCLUSIONS: MULTIPLE IDENTITIES AND EFFECTIVE DEMOCRATIZATION IN AFRICA}

Africa has certain features which may not predispose it to effective democratization. Unlike the countries of Western Europe where most people live in an urban environment, most of Africa's population reside in the rural areas. Though the annual rate of urban population growth outstrips that of the rural area, yet over $60 \%$ of Africa's population of about 500 million are rural dwellers. Rural poverty is also more severe than that of the urban area. Whereas urban dwellers may employ or adopt strategies to escape some imperatives of the consequences of multiple identities, their rural counterparts have little room to maneuver themselves out of the crisis. Though research reports have often indicated the desire of the urban African middle class to be involved in hometown activities, in reality, they desperately look for an escape route from simultaneous rural-urban involvement. This is not surprising as deep involvement in the affairs of the community costs money. On each visit, rural folks expect gifts in cash and in kind. The simultaneous involvement of elites in the rural and urban sphere, apart from straining them financially, exposes them to embezzlement which may have deleterious effects on social services provision. The problem of poverty is thereby compounded. It also has the potential of undermining tradition and political rights at the grassroots. Those who exert tremendous power in the urban space also desperately seek to line up the rural poor as clients.

Individuals may have different identities which can be simultaneously disclosed, but acting out the roles which flow from these identities may provoke a dilemma or even role nonperformance. Role nonperformance creates room for ineffective discharge of functions which may, in combination with other factors, promote poverty. Poverty remains severe in Africa as over half of the population live on less than one dollar a day. 
The corruption of Africa's political elites has prevented the majority of its toiling masses from taking advantage of its rich resource endowment. This corruption arises in the context of conflicting pressure for resources from kinsmen and women. During research interviews, poor people have often openly argued that for them the democratization project is disconnected from their lived experiences what with dilapidated school buildings, unpaid salaries, pension and gratuities in the midst of acute sense of insecurity of lives and property as well as the epileptic infrastructural base. African leaders display open disdain for the ballot box and thus the wishes of the people. The elites simply assume that their money should deliver the votes. It is difficult to appreciate how democracy can work under conditions of widespread poverty and corruption, which in turn often precipitate intra-ethnic and interethnic conflict by forcing multiple identities to the front burner of political competition.

Through whatever lens this is viewed, the simultaneous participation in the rural and the urban sphere takes time and money, it takes more of the time resources of the poor and the physical resources of the middle class. So is the simultaneous or sequential disclosure of identity. This may send contradictory signals. For effective democratization to take root, the people's elected representatives must be monitored but the individuals who are to monitor are also deeply involved in cult-related and intense religious activities which may entail night vigil, clapping, dancing and other forms of rituals and celebrations.

In the midst of the above, is it not surprising that there is any symbol of procedural if not substantive democracy in Africa? The absence of an overwhelming political apathy in Africa in the midst of multiple identities and their all encompassing expression really raises a major theoretical puzzle. There are some other relevant and pertinent issues about the future of democracy in Africa. In Africa, group ownership of land as the main economic resource is common. In fact, several years of capitalism had only begun to marginally erode groups' claim to land ownership and other viable resources. Theoretically, where a lineage or clan owns land, the exercise of individuals rights over such resources is constrained.

In Africa, individuals may exercise the usufruct rights in 
property but not the right of alienation, and law courts have often affirmed the superiority of group rights in property over individual rights. This, no doubt is a fetter in the advancement of capitalism. Yet, liberal democracy can triumph better under conditions of advanced capitalism. The problems of insecurity of life and property, coupled with poor infrastructure have meant that people have to organize themselves in groups to agitate for and create access to better services. Many have learned to take their exit from the state (Osaghae, 1999). Group solidarity thereby gets strengthened. Individuals who enter into politics are expected to exploit their offices to project group rights by placing kith and kins in employment positions even over those with better qualifications. Successful politicians are expected to attract government patronage to the community. The success or failure of politicians is measured in these terms. How is this expectation compatible with the universal competitive claim of democracy on individual basis? The presence of rich mineral resources in fact offers a veritable platform for identity politics as communities are forced to form groups in order to be able to exert sufficient political leverage to obtain a desirable outcome. It is envisaged that had Nigeria's agricultural capitalism progressed, it might have recorded a more impressive outlook in its democratic path than it had been possible under oil rents which more than cocoa are more supportive of group claims and group pressure. Under commercial agriculture, land alienation and sales of labour power had commenced and these were becoming a common place. Really, labour-capital relations had then made some progress.

Thus fractured citizenship rather than common citizenship has become elevated. Nigeria's Constitutions in 1979 and 1999 had given the prime of place to what is referred to as the federal character which in essence project group rights and identities over those of individuals. Jinadu (2004:31-34) has documented several instances whereby fractured citizenship triumphed over common citizenship. To be appointed into high political offices, individuals are forced to mobilize the sponsorship of their ethnic or religious group or other forms of identity. Thus the liberal theory of the state has been argued to be fundamentally flawed because of its parochial, unificationist and assimilationist assumptions (Jinadu, 
2004:12). The assumption by the liberal expectancy school that with capitalism and globalization, the features that separate one group from the other would disappear remains unfulfilled. The radical expectancy school has also failed in that social class affiliation is not exhaustive of identity formation. At some levels in some societies, social class differences are subsumed by other categories. The foregoing pose a serious theoretical challenge to scholars on Africa. In order to advance Africa's democratization, we may have to concede political rights to groups while simultaneously admitting of individual citizenship rights. In most of Africa, children are simultaneously born into groups and individual families. The rights which groups exercise over such children as individuals may be waning but they exist. When individuals die, the groups into which they were born largely bury them. If Africa's practice of democracy, and citizenship claims are to be sustainable and enduring, they must be anchored in the people's culture.

As much as possible, Africa must be supported to be itself in this age of democratization and globalization if the process of abridgement of rights is to be arrested. Inasmuch as the present practices of democracy are tantamount to dis-empowerment, they constitute a fetter on the exercise of citizenship rights. A veritable platform for political disenchantment thereby becomes feasible. The opening sentences of this paper by Kofi Annan and the 2004 Human Development Report bear testimony to the fluidity and elasticity of identities. The view that the end of history is here forecloses tolerance of individuals and groups who choose multiple identities.

\section{REFERENCES}

Achebe, C. (1958) Things Fall Apart, (London: Heinemann).

Ake, C. (1979) Social Science as Imperialism, (Ibadan: University Press).

Archdeacon, T. J. (1984) Becoming American: An Ethnic History (The Free Press).

Bessone, M. (2005) 'Building American Citizenship: a matter of rights or of races', International Social Science Journal, 183, March.

Bibby, C. (1959) Race, Prejudice and Education, (London: 
Heinemann, UNESCO).

Fanon, F. (1969) The Wretched of the Earth, (Britain: Penguin Books).

Faulks, K. (2000) Political Sociology (New York: New York University Press).

Fukayama, F. (2001) 'History in Still Going Our way' R. W. Manshach and E. Rhodes (eds.) Global Politics in a Changing World (Houghton Mifflin).

Grinker, R. R. and C. B. Steiner (eds.) (1997) Perspective on Africa (Oxford: Blackwell Publishers).

Hunttington, S. (2001) 'The Clash of Civilizations', Foreign Affairs, Vol. 72, No.3.

Jinadu, A. (2004). Democratization, Development and the Identity

Crisis in Nigeria, special publication of the University of Lagos Sociological Review (USR), 2004.

Levine, R. (1966) Dreams and Deeds Achievement Motivation in Nigeria (Chicago and London: The University of Chicago Press).

Mamdani, M. (1996) Citizen and Subject: Contemporary Africa and the Legacy of Late Colonialism (New Jersey: Princeton University Press).

Mamdani, M. (2004) Good Muslim, Bad Muslim: America, The Cold War, and the Roots of Terror, (USA: Pantheon Books).

Marshall, T. H. and T. Bottomore (1992) Citizenship and Social Class (London: Photo).

Nnoli, O. (1978) Ethnic Politics in Nigeria (Enugu: Fourth Dimension Publishers).

Osaghae, E. (1999) 'Exiting From The State in Nigeria', African Journal of Political Science, Vol. 4 No. 1.

Peel, J. D.Y. (1983) ljeshas and Nigerians. The Incorporation of a Yoruba Kingdom (London: The Cambridge University Press). Post, K. W. J. and G. D. Jenkins (1973) The Price of Liberty (Cambridge University Press). 